DOI 10.14746/ppuam.2019.9.03

Katarzyna ŁasAK

\title{
The Use of the "Dry Submarine" Technique and Other Allegations in Proceedings Before the United Nations Committee on Enforced Disappearaances. Remarks on the Yrusta v. Argentina case no. 1/2013
}

\section{Introduction}

The United Nations ${ }^{1}$ adopted the International Convention for the Protection of All Persons from Enforced Disappearance on 20 December 2006. ${ }^{2}$ The Convention entered into force on 23 December 2010. ${ }^{3}$ The Convention consists of three parts. Part I contains substantive provisions which establish the obligations of States to prevent and combat enforced disappearances and the crimes associated with them. Part II contains provisions which guarantee procedural protection from acts prohibited by the preceding part of the Convention. Part III opens with a provision which establishes the primacy of national laws or international laws binding upon States Parties which more effectively protect against enforced disappearances. ${ }^{4}$ In addition, Part III contains closing clauses typical for treaties and defines the relationship between the Convention and international humanitarian law. ${ }^{5}$

The Convention not only reflects international law, but also develops it with regulations concerning the prevention of enforced disappearances and the punishment for such offenses. Article 2 defines enforced disappearance as the "arrest, detention, abduction or any other form of deprivation of liberty by agents of the State, or by persons or groups of persons acting with the authorization, support or acquiescence of the State, followed by a refusal to acknowledge the deprivation of liberty or by concealment of the fate or

1 Hereinafter: UN.

2 International Convention for the Protection of all Persons from Enforced Disappearance adopted by the General Assembly of the United Nations on 20 December 2006, United Nation Treaty Series (hereinafter: UNTS), vol. 2716, A/RES/61/177, hereinafter: the Convention.

3 Ibidem.

4 Article $37 \mathrm{~A} / \mathrm{RES} / 61 / 177$.

5 Article 43 A/RES/61/177. 
whereabouts of the disappeared person, which place such a person outside the protection of the law". ${ }^{6}$ The Convention confirms that enforced disappearance constitutes a crime against humanity and gives rise to liability for violation of international law. ${ }^{7}$ Imposing a ban on enforced disappearance, which is not to be revoked under any circumstances, even exceptional ones such as a state of war, is significant progress indeed. ${ }^{8}$

Among the measures to prevent enforced disappearances, the Convention introduces a clear prohibition on the maintenance of secret detention facilities, and requires the introduction of a minimum level of guarantees related to deprivation of liberty, including the compilation and maintenance of one or more up-to-date official registers or records of persons deprived of liberty, and the right of such persons to communicate with and be visited by - family, counsel or another person of their choice. ${ }^{9}$ States Parties are obliged to punish a person who has committed the offence of enforced disappearance if the person is in the State's territory, and if the state has not extradited that person or surrendered him or her to an international criminal tribunal whose jurisdiction it has recognized..$^{10}$ Significantly, enforced disappearance for the purpose of extradition between States Parties to the Convention is not considered to be a political offence, an offence connected with a political offence, or an offence inspired by political motives. Therefore, States Parties cannot refuse a request for extradition based on such an offence on these grounds alone. ${ }^{11}$

An innovation which is not present in other legislative solutions is the actual definition of victim which appears in the Convention. For the purpose of the Convention, a victim does not only mean the disappeared person, but also any individual who has suffered harm as the direct result of an enforced disappearance, such as family members. ${ }^{12}$ The victim is provided with the right to know the truth regarding the circumstances of the enforced disappearance, the progress of the investigation and the fate of the missing person. $^{13}$

Each State Party to the Convention is also to take appropriate measures to ensure that victims of enforced disappearance have the right to obtain just satisfaction and, where appropriate, other forms of reparation, including restitution, rehabilitation, satisfaction, and a guarantee of non-repetition in the future. States are obliged to take appropriate steps regarding the legal situation of disappeared persons whose fate has not been clari-

6 Article 2 A/RES/61/177.

7 Article $5 \mathrm{~A} / \mathrm{RES} / 61 / 177$.

8 Article $1 \mathrm{~A} / \mathrm{RES} / 61 / 177$.

9 Article 17 (1), (2) (f) and (3) A/RES/61/177.

10 Article 11 (1) A/RES/61/177.

11 Article 13 (1) A/RES/61/177.

12 Article 24 (1) A/RES/61/177.

13 Article 24 (2) A/RES/61/177. 
fied and that of their relatives, in fields such as social welfare, financial matters, family law and property rights. ${ }^{14}$

The final provision of Part I of the Convention concerns the protection of a particular group of persons, namely children. ${ }^{15}$ Each State Party must take the necessary measures to prevent and punish the wrongful removal of children who are subjected to enforced disa pearance, children whose father, mother or legal guardian is subjected to enforced disappearance or children born during the imprisonment of a mother. The Convention obliges States Parties to respect the welfare of children who are direct or indirect victims of enforced disappearance, and in the course of searching for them and their identification, protect their right to preserve their identity - or have it re-established - including their nationality, name and family relations. States Parties shall also take the necessary measures to prevent and punish the falsification, concealment or destruction of documents confirming their true identity.

Part II of the Convention establishes the methods for its implementation and, to this end, establishes the Committee on Enforced Disappearances (the Committee). By virtue of the powers conferred upon it, the Committee examines the reports of the States Parties on the measures they have taken to fulfil their obligations under the Convention. ${ }^{16}$ As part of the search and disappearance procedure, the Committee requests that States Parties provide information on the person sought, and makes the recommendations it deems necessary to protect the person concerned. ${ }^{17}$ The Committee also examines the communications of individuals claiming to be victims of violations of the Convention ${ }^{18}$ and communications from States Parties claiming that another State Party is not fulfilling its obligations under the Convention. ${ }^{19}$ If the Committee receives information indicating that another State Party has seriously violated the provisions of the Convention, it may, after consultation with the State Party concerned, request that one or more of its members visit and report back to it promptly. ${ }^{20}$ Finally, if the information received indicates that enforced disappearances are widespread or systematic, the Committee may urgently bring the matter to the attention of the General Assembly of the United Nations, through the Secretary-General of the United Nations. ${ }^{21}$

14 Article 24 (4), (5) and (6) A/RES/61/177.

15 Article 25 A/RES/61/177.

16 Article $29 \mathrm{~A} / \mathrm{RES} / 61 / 177$.

17 Article 30 A/RES/61/177.

18 Article $31 \mathrm{~A} / \mathrm{RES} / 61 / 177$.

19 Article $32 \mathrm{~A} / \mathrm{RES} / 61 / 177$.

20 Article 33 A/RES/61/177.

21 Article 34 A/RES/61/177. 
44 | Adam Mickiewicz University Law Review

\section{The Yrusta v. Argentina case}

\section{Facts and allegations}

On March 11, 2016, the Committee issued its first views on the first case it considered, and so far the only one on an individual action. ${ }^{22}$ The authors of the communication, the sisters of Roberto Agustín Yrusta, brought the case against Argentina, due to the disappearance of their brother. The sisters claimed that they had been victims of violations of those provisions of the Convention which: prohibit enforced disappearances ${ }^{23}$; require that appropriate measures be taken to prosecute enforced disappearances and punish those responsible for these crimes $^{24}$; establish the right to report that another person has been the victim of enforced disappearance, guaranteeing a comprehensive and impartial investigation and stipulating that it must proceed even in the absence of a formal complaint when there are reasonable grounds for believing that a person has been the victim of enforced disappearance ${ }^{25}$; oblige the State Party to cooperate and provide legal assistance to victims of enforced disappearance, as well as to search for, locate and release missing persons, and, in the event of their death, assist with the exhumation, identification and return of their remains ${ }^{26}$; stipulate that the authorities which are responsible for deciding on the deprivation of liberty must be clearly indicated in the national legislation, and establish the right of a person deprived of liberty to communicate with and see their counsel or person of his or her choice ${ }^{27}$; guarantee a person with a legitimate interest the right to obtain basic information concerning the circumstances of deprivation of liberty to, and protect this person from ill-treatment in the search for such information ${ }^{28}$; guarantee the right to a prompt and effective judicial remedy as a means of obtaining without delay information referred to in paragraph 1 of Article 1829; oblige States to ensure the training of public officials on the issue of enforced disappearances ${ }^{30}$; define the concept of victim and establish the rights involved in the proceedings which shed light on enforced disappearance and to remedy the resulting damage. ${ }^{31}$

In 2005 Roberto Agustín Yrusta was sentenced to 8 years imprisonment for aggravated robbery involving the use of a firearm. For more than 3 years of his prison sentence in the Province of Córdoba, Mr. Yrusta was subjected to torture and inhuman

22 Decision of 12 April 2016 of the Committee on Enforced Disappearances (hereinafter: CED) no. 1/2013 in the case Yrusta v. Argentina, CED/C/10/D/1/2013.

23 Articles 1 and $2 \mathrm{~A} / \mathrm{RES} / 61 / 177$.

24 Article $3 \mathrm{~A} / \mathrm{RES} / 61 / 177$.

25 Article 12 (1) and (2) A/RES/61/177.

26 Article $15 \mathrm{~A} / \mathrm{RES} / 61 / 177$.

27 Article 17 (2) (c) and (d) A/RES/61/177.

28 Article 18 A/RES/61/177.

29 Article $20 \mathrm{~A} / \mathrm{RES} / 61 / 177$.

30 Article 23 A/RES/61/177.

31 Article 24 A/RES/61/177. 
and degrading treatment. This involved solitary confinement, being shackled to a bed, intimidation, beating, the use of the "dry submarine" technique ${ }^{32}$, and transfers from one cell to another. In 2012, Mr. Yrusta filed a complaint against members of the Córdoba Prison Service at the competent provincial court. At the end of the same year, he gave an interview to local television during which he spoke publicly about how he was being treated by prison officers. Mr. Yrusta's family claimed that from that time on their brother's ill-treatment intensified.

Fearing for his own life, Mr. Yrusta requested that the prison authorities in Córdoba transfer him to the prison in the Province of Santiago del Estero, where he had family. However, at the beginning of 2016 he was transferred to a prison in Coronda, in the province of Santa Fe. The prisoner, unable to read and not informed as to his whereabouts, believed that he was being transferred to the requested institution.

Mr. Yrusta's family repeatedly asked the prison authorities to provide information on their brother's whereabouts, but no answer was forthcoming. This situation lasted for more than 7 days, during which time - in the opinion of the authors - their brother became a victim of enforced disappearance. When Mr. Yrusta was able to contact his family again, it became apparent that the Coronda prison officers were subjecting him to similar ill-treatment to that which he had suffered in the previous prison.

On February 7, 2013, 10 months before the end of the sentence, the prison authorities informed the family that Mr. Yrusta had committed suicide by hanging himself in his cell. According to the Institute of Forensic Medicine in Santa Fe, the most likely cause of death was by "sudden compression of the neck by an object with elastic properties (which was not furnished along with the body of the deceased)". ${ }^{33}$

Mr. Yrusta's body was delivered to the family on February 8, 2013. The state of the corpse indicated that Mr. Yrusta had been beaten and that rubber bullets had been fired at him. No injuries similar to those that would result from death by hanging were found. In view of the above, it was decided to contest the version of events reported by the authorities of the State Party.

On February 26, 2013, the Yrusta family, supported by Coordinadora Anticarcelaria de Córdoba $a^{34}$ appealed to the Santa Fe Provincial Public Defender to intervene in the case of Mr. Yrusta, which had been referred to the Santa Fe Criminal Investigation Court. On April 22, 2013, this request was denied, on the grounds that the Public Defender lacked the capacity to bring such an action. The case file was also not made available to him. Neither did the court in question allow the deceased's family to participate in the proceedings as parties to the prosecution. The Santa Fe Criminal Court of Appeal had not considered the applicants' petition by the time the initial communication was

32 Suffocation by means of a plastic bag.

33 CED/C/10/D/1/2013, para. 2.4.

34 Córdoba Anti-Prison Coordinating Committee. 
submitted to the Committee. No public authority helped in any way with the process of clarifying the real causes of Roberto Agustín Yrusta's death.

\section{The Admissibility of the Communication}

According to Article 31 (1) of the Convention, the Committee shall not admit any communications if they concern a State Party which has not declared that it recognizes the Committee's competence to receive and consider communications from or on behalf of persons under its jurisdiction who claim to be victims of violation by this State Party to the provisions of the Convention. Argentina made such a declaration on June 11, 2008. The Convention entered into force for this State on December 30, 2010.

Article 31 (2) (a) of the Convention provides for the Committee does not consider anonymous communications which make it impossible to establish the identity of the persons who direct them to the Committee, and yet at the same time claim to be the victims of certain human rights violations. On this basis, the communication in the case in question was admissible because the authors clearly defined themselves in the content in such a way that they could be identified.

In accordance with Article 31 (2) (c) of the Convention, it was ensured that the case of the Yrusta family - in the form presented to the Committee - had not previously been dealt with by another international body dealing with investigations or disputes of the same nature.

The authors alleged that the State Party was in violation of Articles 1, 2, 3, 12 (1) and (2), 15, 17 (2) (c) and (d), 18, 20, 23 and 24 of the Convention, on the basis of the facts described in the communication, and namely: the alleged enforced disappearance of Mr. Yrusta; his transfer in January 2013 to another prison than that which he had requested; the torture and inhuman and degrading treatment during three years of imprisonment; the lack of information concerning the whereabouts of the prisoner while he was being transferred to another prison, the name and location of which was not revealed to the family; the impossibility of communicating with the prisoner for over 7 days, until he was finally allowed to call his family; the authors' and mother's lack of access to a court that would provide a judgment on the lawfulness of the situation within a reasonable time; the death of Mr. Yrusta in the prison to which he was transferred; the investigation into the causes and circumstances of his death; and the failure to allow the sisters of the deceased to participate in proceedings before national authorities as parties to the prosecution.

In accordance with Article 31 (2) (b), a communication is inadmissible if it constitutes an abuse of the right of submission of such communications or is incompatible with the provisions of the Convention. Therefore, the Committee had to examine whether all alleged violations of the Convention fall within its scope. In this regard, the Committee found that some of the authors' claims did not fall within the competence ratione 
materiae of the Committee, namely: the transfer of Mr. Yrusta without his consent; the acts of torture and inhuman and degrading treatment; and his death and the subsequent investigation. However, the following allegations were seen to fall within the Committee's competence: the alleged enforced disappearance of Mr. Yrusta for a period of more than seven days after his transfer from Córdoba to Cordona; the failure to provide information to his family about the transfer; the impossibility of contacting the prisoner for more than seven days; the fact it was impossible to gain access to a court that would reach a prompt decision concerning the lawfulness of Mr. Yrusta's situation after his prison transfer; the absence of any investigation into the enforced disappearance; and refusing to allow the deceased family members to take part in the investigation into their brother's case as parties to the prosecution.

The Committee noted that in the seven days during which the authors allege that Mr. Yrusta was subject to enforced disappearance, his family repeatedly asked the prison authorities for information regarding his location, no reply was given. The Committee also took into account the authors' claim that there was no possibility of initiating legal proceedings under national law, through which a decision could be made on the lawfulness of Mr. Yrusta's situation when he was transferred to the prison in Coronda. The Committee pointed out that the State Party had not provided any information on the existence or non-existence of domestic remedies in such circumstances.

The Committee observed it had taken over one and a half years - since 26 February 2013, when the authors submitted their request to join the case as plaintiffs - for the Appeal Court to deny their appeal. In the opinion of the Committee, the State Party did not provide any convincing arguments to justify such a delay. The Argentine authorities also failed to provide information indicating which State body had the competence to represent the authors in the proceedings before the national authorities, and neglected to inform the authors concerning the progress made in investigating the alleged enforced disappearance of Mr. Yrusta for over 7 days. Finally, the State Party did not respond to the question of whether the domestic law provides for such remedies. As a result, the Committee ruled that the only remedies available to the authors were not implemented within a reasonable time, and alternatives did not exist.

With regard to the above, the Committee considered the communication admissible in respect of the alleged violations of Articles 1, 2, 12 (1) and (2), 17, 18, 20 and 24 of the Convention, and requested that the State Party submit the comments on its substance. Despite five extensions, the Argentine authorities did not comment on the case.

\section{Assessing the Merits of the Communication}

Assessment of the claims contained in the communication had to precede the decision on whether Mr. Yrusta had been subjected to enforced disappearance, as defined in Article 2 of the Convention. The authors claimed that their relative had suffered enforced 
disappearance while he was being moved from Córdoba prison to Coronda, because during this time neither he nor any family members knew where he was being transported, and for seven days the family was unable to obtain information from the prison authorities as to where the prisoner was located. In addition, the prison records - to which the family and the prisoner's attorney had access - did not make it possible to identify him unambiguously, as he was represented by three different names, which in turn prevented him from being located during subsequent stages of the detention. The registers did not contain information on who had ordered the transfer and for what reasons, or on the date and place of the transfer.

For the purposes of the Convention, and in accordance with Article 2, enforced disappearance begins with the arrest, detention, abduction or any other form of deprivation of liberty. Unlawful detention or arrest may lead to enforced disappearance ${ }^{35}$, as can the transport of as prisoner, as happened in the case in question. In addition, in order to establish that enforced disappearance has taken place, it is necessary that the deprivation of liberty be accompanied by a refusal to recognize this deprivation, or to hide the fate or location of the person, a state of affairs that thereby places the person outside the protection of the law, irrespective of the duration of the deprivation of liberty or the concealment. ${ }^{36}$

In the opinion of the Committee, the refusal to provide information concerning where Mr. Yrusta was at the time specified in the communication constituted a form of concealment of his fate or whereabouts, as defined in Article 2 of the Convention. Furthermore, throughout the whole time in question, Mr. Yrusta was not able to contact anyone or receive any visits. In addition, Mr. Yrusta and his family had no access to a court which could make a timely decision on the lawfulness of the prisoner's transport. The Committee held that concealing the prisoner's fate and whereabouts resulted in his being deprived of legal protection. Persons deprived of liberty following enforced disappearance cannot avail themselves of the legal remedies provided for by national law to ensure that a court can determine the legality of the deprivation of liberty, as in the case of Mr. Yrusta. Consequently, the Committee ruled that the actions that Mr. Yrusta had been subjected to for more than 7 days, in connection with his transfer to another prison, constituted enforced disappearance, contrary to Articles 1 and 2 of the Convention.

With regard to the allegations concerning Articles 17 and 18 of the Convention, it should be remembered that at the time of the events which led to the communication, Mr. Yrusta was serving a prison sentence. According to Article 17, nobody should be detained in secret locations, and the State Party should ensure that records of persons deprived of their liberty are maintained and updated. Whereas Article 18 (1) (d) guarantees that any person with a legitimate interest - such as relatives of the detainee, their agent or attor-

35 General comment of the Working Group on Enforced or Involuntary Disappearances on the definition of enforced disappearances, A/HRC/7/2, para. 26.

36 Ibidem, paras. 8-9. 
ney - should have access to information concerning the whereabouts of the detainee, and when the detainee is transported to another place of detention, the place and the authority responsible for the transfer should be specified.

It should be mentioned that Mr. Yrusta was transported under the pretext that his request was being taken into consideration, namely the change his place of imprisonment so that he could be closer to his family - from Córdoba to the province of Santiago del Estero. Information on the actual state of affairs was not provided by any representative of the authorities, to either the prisoner or the members of his family. Not only did the family not know where Mr. Yrusta was, they were not even told that he had been taken to another prison. Article 20 (1) of the Convention allows that the right of family members to be informed can be restricted, subject to certain preconditions, which however the Committee judged to be inapplicable in this case. The State Party did not provide any explanation as to relevant legislation in force in this area. The Committee held that depriving the prisoner and his family of information for seven days, including the family members who submitted the communication, violated Articles 17 (1), 18 (1) and 20 (1) of the Convention. The Committee also found the State Party to be in violation of Article 20 (2) of the Convention, because the family did not have effective access to a court as a means of obtaining information without delay, within the meaning of Article 18 (1).

As regards the authors' claim that they were prevented from taking an active part in the investigation of their brother's case, including his enforced disappearance, as they were denied the status of private criminal plaintiffs, the Committee recalled that, according to Article 24 of the Convention, apart from the disappeared person, a 'victim' is also defined as a person who has suffered directly as a result of enforced disappearance. The State Party did not provide any evidence that the sisters of the disappeared did not fall under this category of persons. In the Committee's view, the anxiety and suffering experienced by the authors of the communication, due to the lack of information explaining what had happened to their brother, was intensified by the de facto refusal to recognize their status as victims, which in turn led to their re-victimization - which is also in conflict with the principles of the Convention.

The Committee noted that the proceedings initiated with Mr. Yrusta's case dealt with the causes and circumstances of his death, and possible criminal liability associated with them. However, none of the files attached to the communication referred to the issue of enforced disappearance. The fact that the competent national authority took a year to make a decision concerning the participation of the Yrusta family in the case of Mr. Yrusta was in itself a violation of Articles 12 (1) and 24 (1), (2) and (3) of the Convention. After such a long period of time, the possibility of active and effective participation in the proceedings is reduced to such an extent that the damages resulting from the lack of enforcement of the relevant law becomes irreparable, and thus violates the victim's right to know the truth. 
The Committee held that there had been violations of articles 1, 2, 12 (1), 17, 18, 20 and 24 (1), (2) and (3) of the Convention in relation to Mr. Yrusta, and 12 (1), 18, 20 and 24 (1), (2) and (3) of the Convention with respect to the authors of the communication.

Acting on the basis of article 31 (5) of the Convention, the Committee recommended that the State Party recognize the victim status of the authors of the communication, which would enable them to participate effectively in proceedings aimed at clarifying the death and enforced disappearance of their brother. The investigation into the circumstances of Mr. Yrusta's death should also include a comprehensive and detailed investigation into his enforced disappearance during his transport from Córdoba to Santa Fe. The perpetrators of the violations should be prosecuted, judged and punished. According to Article 24 (4) and (5) of the Convention, the authors of the communication should be vindicated and provided with prompt, fair and adequate compensation. Pursuant to Articles 24 (5) (d) and 17 and 18 of the Convention, the State Party must ensure that in the future similar violations do not occur, that prison registers are compiled and maintained, and that all persons with a legitimate interest will have access to all relevant information.

The Argentine authorities were obliged to publish and disseminate the Committee's views to the fullest extent possible, above all among members of the security forces and prisoner personnel, but not only in these circles.

The Committee requested that, within six months from receiving its views, the State Party should provide information on the measures taken to implement its recommendations. However, by the time of the 12th session of the Committee, Argentina had not provided such information. ${ }^{37}$ Furthermore, the information available to the Committee shows that the State Party had not taken any steps to implement the recommendations contained in the views. Emphasizing that such nonfeasance continued and thus aggravated the violations of the rights of the authors of the communications, the Committee requested that the Argentine authorities submit the requested information within 2 months of receiving a verbal warning on this issue, and decided to consider it at its thirteenth session, which took place from 4-15 September 2017. ${ }^{38}$ In 2018, the Committee examined the follow-up information submitted by the State Party. As Argentina had not fully implemented its recommendations, the Committee decided to maintain the follow-up procedure and to send a note verbale to the permanent mission of the State Party and a letter to the authors informing them accordingly, which took place in $2019^{39}$.

$37<$ http://tbinternet.ohchr.org/_layouts/treatybodyexternal/SessionDetails1.aspx?SessionID=1102 \&Lang=en>.

38 Report of the CED, General Assembly Official Records, 72 Session, Supplement no. 56, A/72/76, para. 89.

39 Report of the CED, General Assembly Official Records, 74 Session, Supplement no. 56, A/73/56, para. 59 and Report of the CED, General Assembly Official Records, 74 Session, Supplement no. 56, A/74/56, para. 9 (p). 


\section{Comments}

The Convention belongs to the human rights treaties of narrow scope. It protects the individual from enforced disappearance, and from acts or nonfeasance inspired by enforced disappearance which can accompany or be the consequence of this crime being committed by the state or by public or private law entities authorized by the state. It is clear from Article 2 of the Convention that anyone can participate in the crime of enforced disappearance, albeit in different forms. However, not all the actions of the person who is involved in the crime of enforced disappearance constitute a crime under the Convention. Yet, the refusal to admit that a person has been abducted, or obfuscating the location at which a person has been detained, do both fall under the definition of enforced disappearance expressed in Article 2 of the Convention, and thus constitute a basis for initiating the complaint procedure under Article 31.

In many cases, or even the majority of them, enforced disappearance rarely occurs out of nowhere, in an isolated manner, without being related to other crimes. Usually enforced disappearance is another method for attempting to exert pressure on a person deprived of liberty, and on the members of his or her family, or persons from the same political circle, or on persons in any other way connected with him or her. This type of offense takes place after acts classified by international law as ill-treatment, rather than as a pretext for such acts, as the intent is to cover up, especially when the aim is to prevent a missing person from being found. The kinds of treatment applied to those deprived of liberty, including enforced disappearance, is symptomatic of an unhealthy social fabric in the state, and is evident in broader political and economic spheres, not just in the prison service. It could even be argued that enforced disappearance in such situations is usually the final manifestation of ill-treatment, although it is impossible to exclude an alternative sequence of events.

Therefore, enforced disappearance is a very sensitive issue, making its regulation even more difficult and complex than that typically involved in the legislative process of international law. Legislators, including international ones, determine the principles and objectives of acts to be adopted a priori, in the interests of the majority taking part in the voting. For these reasons, in the Convention enforced disappearance became an illegal act separate from the notion of ill-treatment in international law. The Convention does not in practice rule out the convergence and multiple configurations of enforced disappearance and ill-treatment. ${ }^{40}$ Nevertheless, for the implementation of the Convention,

40 It should be recalled that in the report prepared for the UN General Assembly by the Commission on Human Rights Special Rapporteur on the question of torture and other cruel, inhuman or degrading treatment or punishment, indicated the admissibility of enforced disappearances as a kind of torture. United Nations General Assembly, Report of the Special Rapporteur on the question of torture and other cruel, inhuman or degrading treatment or punishment, Question of torture and other cruel, inhuman or degrading treatment or punishment, $A / 56 / 156$, 3 July 2001, paras. 9-16. 
enforced disappearance was limited to the definition in Article 2, binding it strongly with another normative construct, namely the protection of freedom and personal security. The issue of ill-treatment falls outside the scope of the Convention provisions. Accordingly, any allegations of any form of ill-treatment, for example the use of the 'dry submarine' technique - although such treatment can be correlated with enforced disappearance, as it was in the Yrusta case - fall outside the scope of the Convention and, as expected, these allegations had to be rejected.

The Yrusta family could have submitted claims for alleged ill-treatment under the Convention against Torture and Other Cruel, Inhuman or Degrading Treatment or Punishment of 1984 (CAT) ${ }^{41}$, the Optional Protocol to the Convention against Torture and other Cruel, Inhuman or Degrading Treatment or Punishment of 2002 (CATOP) $)^{42}$, or the American Convention on Human Rights of 1969 (ACHR). ${ }^{43}$ Argentina is a party to these treaties and has recognized the competence of their supervisory bodies to deal with individual complaints against it ${ }^{44}$. Nevertheless, from the perspective of the Yrusta family or others, to submit simultaneous claims concerning alleged enforced disappearance and ill-treatment would seem to be an unacceptable solution, due to the time, cost and personal commitment, especially the emotional dimension. Allocating justice according to thematic categories, which is in principle permissible and justifiable, can - in the case of some complainants - turn out to be a choice that is unsatisfactory and therefore unreasonable, as in the Yrusta case. The interesting aspect of the Convention is that, in this context, it provides protection from ill-treatment, intimidation or punishment when persons with a legitimate interest search for information concerning a person deprived of liberty. ${ }^{45}$ The relatives of Roberto Agustín Yrusta could therefore have demanded such protection as the required conditions were fulfilled, but solely with regard to them.

In its decision on the Yrusta case, the Committee treated enforced disappearance as was intended by the legislator, namely as an serious offense, unrelated to any other violation of fundamental human rights and freedoms, or to any unlawful act as defined by criminal law, whether international or national. At the same time, the Committee reaffirmed its jurisprudence in the area under discussion, according to which only the criminalization of enforced disappearance as an autonomous offense would enable the State

41 General Assembly Resolution of 10 December 1984, UNTS, vol. 1465, p. 85, A/RES39/46.

42 General Assembly Resolution of 9 January 2003, UNTS, vol. 2375, p. 237,

43 American Convention on Human Rights adopted on November 22 1969, UNTS, vol.1144, p. 123, hereinafter: ACHR.

44 Individual complaint procedure under CAT <http://tbinternet.ohchr.org/_layouts/TreatyBodyExternal/Treaty.aspx?CountryID=7\&Lang=en> Individual complaint procedure under AHCR $<$ http://www.cidh.oas.org/basicos/english/Basic4.Amer.Conv.Ratif.htm>.

45 Article 18 (2) of the ACHR. 
Party to meet its obligations under Articles 2, 4, 6, 7 and 8 of the Convention. ${ }^{46}$ It would be inappropriate to establish criminal liability for enforced disappearance by subsuming it under the various provisions of criminal law, because it constitutes one offense. Enforced disappearance is complex, not because it consists of elements of different crimes committed in secrecy, but rather because it has implications for the whole situation of the imprisoned and his or her rights. It does not suffice to show that the domestic law penalizes certain acts which are directed against the freedom of persons (for example, unlawful detention or arrest, alleged deprivation of liberty or abduction) and that the provisions contain some of the elements that constitute enforced disappearance as defined Article 2 of the Convention. ${ }^{47}$ The situation of Argentina is, in this context, particularly interesting, as in its comments on the only government report submitted so far, the Committee welcomed an amendment to the penal code which introduced a new, separate type of offense of enforced disappearance, but at the same time the Committee indicated the difficulties in implementing the newly introduced provisions. ${ }^{48}$ The position adopted by the Committee then confirmed its views on the Yrusta case.

According to Article 2 of the Convention, and as exemplified by the Committee in its case-law, enforced disappearance is carried out by representatives of the State or by persons or groups of persons acting with the authorization, support or acquiescence of the State. ${ }^{49}$ This constitutive element of the definition was realised somewhat atypically in the Yrusta case. Mr. Yrusta disappeared during his imprisonment. Apparently, the deceased was under the care of the State Party's authority, which had authorised the prison services to be responsible for his life, health and safety. Nevertheless, the question arises of whether he was subject to enforced disappearance in a manner covered by the Convention, namely arrested, detained, abducted or otherwise deprived of his liberty - when Mr. Yrusta had already been deprived of his liberty, following a lawful judgment, and while actually being imprisoned. The Committee, in holding that Mr. Yrusta had been subjected to enforced disappearance, considering the circumstances of the case, allowed that Article 2 of the Convention applies to situations when liberty is deprived in openly functioning state prison systems. Given that the deprivation of liberty is only one of

46 CED, Concluding observations on the report submitted by Serbia under article 29, paragraph 1, of the International Convention for the Protection of all Persons from Enforced Disappearances, CED/C/SRB/CO/1, 16 March 2015, para. 10.

47 CED, Concluding observations on the report submitted by Armenia under article 29, paragraph 1, of the International Convention for the Protection of all Persons from Enforced Disappearances, CED/C/ARM/CO/1, 13 March 2015, para. 11.

48 CED, Concluding observations on the report submitted by Argentina under article 29, paragraph 1, of the International Convention for the Protection of all Persons from Enforced Disappearances, CED/C/ARG/CO/1,12 December 2013, para. 12.

49 CED, Concluding observations on the report submitted by Germany under article 29, paragraph 1, of the International Convention for the Protection of all Persons from Enforced Disappearances, CED/C/GER/CO/1,10 April 2014, para. 7. 
the conditions required for enforced disappearance, and regarding that this deprivation can take many forms, other factors must play a role, such as when the prison authorities refuse to provide any information about the prisoner, most crucially concerning his or her location, as in the case in question, and consequently it becomes impossible to provide the protection provided for by law. Only after all the criteria required to establish enforced disappearance have been met can it be stated that there has been a violation of the prohibition of Article 1 of the Convention. ${ }^{50}$ There is no doubt that the enforced disappearance of Mr. Yrusta was caused by acts contrary to the responsibilities of the State Party towards a person deprived of liberty, and that the violation took place by further deprivation of liberty, entailing that he found himself in a vicious circle, which he was unable to escape from himself. Help from family members was also precluded due to their not being provided with the necessary information.

Another important issue which may have an impact on the understanding of enforced disappearance in the Convention is the issue of time. Article 2 is silent on this subject. The legislator did not specify a temporal boundary, after the crossing of which arrest, detention, abduction or deprivation of liberty in another form are considered to constitute enforced disappearance, and thus the issue was left to the discretion of the supervisory body. Consideration of the literal wording of the definition of enforced disappearance in the Convention suggests that the element of time, if it is at all meaningful to a decision, is merely subordinate. Teleological interpretation, applied to the facts of a particular case, may prescribe caution in their subsumption, even if the conditions considered necessary to establish enforced disappearance have been fulfilled. In this case, the period of 7 days during which Mr. Yrusta could not personally determine where he was and why, and in which the Yrusta family were in no way able to obtain information on the whereabouts or fate of their relative, was precisely and repeatedly indicated at each stage of the proceedings before the Committee, starting from the submission of the communication through to the finding of violation of Articles 1 and 2. However, when deciding on the substance of the matter, the Committee did not refer more broadly to the effect of temporality on the legal classification. It may seem that, in the light of the Yrusta views, although the Committee did not ignore the element of time, given the potential strength of its interaction with elements of the definition of enforced disappearance in the Convention, it was not a decisive factor.

The prohibition on enforced disappearances was developed and strengthened by: prohibiting the detention of persons in secret places $^{51}$, formulating the obligation to establish

$50 \mathrm{CED}$, Concluding observations on the report submitted by Netherlands under article 29, paragraph 1, of the International Convention for the Protection of all Persons from Enforced Disappearances, CED/C/NLD /CO/1, 10 April 2014, para. 14.

51 Article 17 (1) A/RES/61/177. 
a guarantee of freedom and personal security in the national legal system ${ }^{52}$, and obliging the States Parties to organize and maintain registers or files of persons deprived of liberty. ${ }^{53}$ In order to implement the provisions of Article 17 of the Convention, it is necessary to close secret institutions for depriving people of liberty, irrespective of their form and purpose, if such exist in the territory of the country, or they should be converted into clearly identified detention centres within the meaning of the Convention, taking into account relevant legislative acts. Those who violate the prohibition on Article 17 (1) must be punished in proportion to the degree of their culpability and the victims should be properly compensated and rehabilitated. ${ }^{54}$ The State should take the necessary legislative measures, and any other required measures, to ensure that any person, irrespective of his or her status $^{55}$, and regardless of the type of offense he or she is alleged to have committed ${ }^{56}$, is guaranteed the material and procedural protection provided for in the Convention, particularly in Article 17, and other relevant instruments that protect human rights. ${ }^{57}$

It is preferable that the guarantees of habeas corpus be enshrined in basic state law, and that they be developed through ordinary legislation. Deprivation of liberty may only take place on the basis of a decision issued in accordance with the law by a competent state authority. ${ }^{58}$ Such a decision must be implemented in official centres for the deprivation of liberty, which are subject to constant supervision. Any person deprived of liberty should be able to maintain prompt and regular contact with their family, counsel or any other designated person, and in the case of foreigners, with the consular office. ${ }^{59}$ Without exception, all cases of deprivation of liberty must be subject to a single registration system, containing - as a minimum the information required under Article 17 (3), and must be regularly updated and checked. ${ }^{60}$ It is unacceptable for the right to liberty and personal security within the meaning of the

52 Article 17 (2) A/RES/61/177.

53 Article 17 (3) A/RES/61/177.

54 CED, Concluding observations on the report submitted by Iraq under article 29, paragraph 1, of the International Convention for the Protection of all Persons from Enforced Disappearances, CED/C/IRQ/CO/1, 10 April 2014, para. 30.

55 E.g. immigrants.

56 E.g. a coup.

57 CED, Concluding observations on the report submitted by Iraq under article 29, paragraph 1, of the International Convention for the Protection of all Persons from Enforced Disappearances, CED/C/IRQ/CO/1, 10 April 2014,, para. 28.

58 CED, Concluding observations on the report submitted by Burkina Faso under article 29, paragraph 1, of the International Convention for the Protection of all Persons from Enforced Disappearances, CED/C/BFA /CO/1, 24 May 2016, paras. 31-2.

59 CED, Concluding observations the report submitted by Kazakhstan under article 29, paragraph 1, of the International Convention for the Protection of all Persons from Enforced Disappearances, CED/C/KAZ/CO/1,26 May 2016, para. 20.

60 CED, Concluding observations on the report submitted by Tunisia under article 29, paragraph 1, of the International Convention for the Protection of all Persons from Enforced Disappearances, CED/C/TUN/CO/1, 25 May 2016, para. 30. 
Convention to be suspended, even if a state of emergency or war arises. ${ }^{61}$ In addition, with regard to the States Parties to the CAT-OP, the Committee welcomes the correct implementation of the national preventive mechanism ${ }^{62}$, even though it does not have jurisdiction over this area. In all likelihood this is because at least some forms of deprivation of liberty that violate Article 17 may also be simultaneously classed as torture or other cruel, inhuman or degrading treatment or punishment. Another reason may be the need for all the bodies that deal with human rights to cooperate, at least within the UN, in the fight against torture and associated practices.

Application of the above principles for the interpretation of Article 17 of the Convention regarding the case in question first requires consideration of whether Roberto Agustín Yrusta was indeed held in a secret place. It must be pointed out that he was imprisoned in a place which was certainly an identifiable state penitentiary centre in Argentina. During his imprisonment, Mr. Yrusta was supposed to be transported to another, similar institution, but for seven days it was impossible to determine where he was and what was happening to him. Argentina, one of the few states to report to the Committee, stated that it had fully implemented the prohibition on people being held in secret places. ${ }^{63}$ This would entail that Mr. Yrusta was not being held in a secret place of detention, since no such place exists in the territory of the country of which he was a citizen. It is possible accept a twofold understanding of secrecy, but not of places where people are detained. The secret detention of persons defined in the Convention is essentially deprivation of liberty in places that are not listed on any official list of state penitentiary institutions. However, it is possible that a place of detention can be found on such a list, but that the information concerning a person imprisoned in it is kept secret. It is hard to say which these possibilities describes the state of affairs in the Yrusta case, as until now the information presented to the Committee has been inadequate. In any case, it was acknowledged admissible that there had been a violation of the prohibition on

61 The introduction of an incommunicado detention regime, which allows discretionary determination of the duration of deprived liberty, although within the limits established by national law, in connection with an increased threat to the security of the state as a result of terrorist attacks, makes it possible to deny a person the ability to appoint counsel, to only allow the person to talk with their counsel with an officer's assistance, and to not inform a selected person about the fact of deprivation of liberty or location, all of which is contrary to Article 17 of the Convention. CED, Concluding observations on the report submitted by Montenegro under article 29, paragraph 1, of the International Convention for the Protection of all Persons from Enforced Disappearances, CED/C/MNE/CO/1, 16 October 2015, paras. 24-5.

62 Articles 17-23 A/RES/61/177. In Armenia, such a mechanism is the Human Rights Defender. CED, Concluding observations on the report submitted by Armenia under article 29, paragraph 1, of the International Convention for the Protection of all Persons from Enforced Disappearances, CED/C/ARM/CO/1,13 March 2015, paras. 20-1.

$63 \mathrm{CED}$, Concluding observations on the report submitted by Argentina under article 29, paragraph 1, of the International Convention for the Protection of all Persons from Enforced Disappearances, CED/C/ARG/CO/1, 12 December 2013, para. 24. 
people being held in secret places. For similar reasons, it is impossible to determine with complete certainty who made the decision to secretly detain the prisoner. Nevertheless, taking into account the available facts of the case regarding Mr. Yrusta's transport from one prison to another, the obstacles encountered by the family during the investigation of his disappearance, and the prolonged silence of the Argentine Government in the proceedings before the Committee, suggests that the issue will remain secret, as an adequate decision was not taken by an authorized state body, under the law and within the boundaries and procedure laid down, but it was the result of the discretionary treatment of the prisoner by unidentified prison officials. ${ }^{64}$ Preventing contact with the family and incorrectly entering data into the register of persons deprived of their liberty, and possibly the falsification of this data ${ }^{65}$, led to there being no possibility of determining the fate of Mr. Yrusta or providing him with legal protection ${ }^{66}$.

While a person deprived of liberty has the right to know where he or she is detained, and for what reasons and on what basis, Article 18 of the Convention stipulates the right of every person generally defined as having a legitimate interest to obtain the same information. The Convention expressly refers to the people legitimately entitled to search for and demand information concerning the detainee - namely their relatives, representatives or counsel. Since one of the safeguards against people's being kept in secret places is the right of someone who has been deprived of their liberty to communicate with the people indicated ${ }^{67}$, any of these people may be expected to demand access to information about him or her. Furthermore, the purpose of the provision is to guarantee protection to those who seek such information - and seek to participate in proceedings which aim to investigate the circumstances of enforced disappearance - from intimidation and mistreatment aimed at forcing them to resign from the action taken. ${ }^{68}$

Information that should be made available is that which is of fundamental importance for identifying the place of detention, including data for updating the state of affairs; determining the health condition of the detainee; identifying the causes of possible death; the circumstances of the release; and establishing the authorities that issued the decisions shaping the legal and factual situation of the detainee during the whole period when he or she was deprived of liberty. According to the Convention, the basic

64 It often happens when the prison authorities want to hide the fact of applying extra-judicial punishment to prisoners. Ibidem, para. 26.

65 In the report on Argentina, the Committee pointed out the lack of standard computerised procedures for registering persons deprived of liberty in that country and recommended their urgent implementation. Ibidem, para. 29.

66 Admittedly, as part of implementing the CAT-OP, Argentina introduced the Prison System Ombudsman, but it is still not fully effective because it is not possible to monitor all penitentiary centres, due to lack of access. Ibid., para. 30 .

67 Article 17 (2) (d) A/RES/61/177.

68 Article 18 (2) A/RES/61/177. 
source of information an authorized person may demand to see is the registers or files of persons deprived of their liberty, which links the right provided in Article 18 (1) and the obligation of the State Party stipulated in Article 17 (3). Considering the importance of the information sought, the Convention requires that sanctions be imposed for conduct that refuses to provide information or providing inaccurate information. ${ }^{69}$

The extent of the information that those entitled may demand under Article 18 (1) is qualified by the term as 'at least', which entails that a State Party is always able to provide claimants with a more extended version, but may not limit it, except in cases permitted by the Convention. Personal data, especially medical information, including genetic information, cannot be used for other purposes than the search for the disappeared person. The collection, processing, use and storage of this data will infringe the human dignity of such a person and constitute a violation his or her human rights. ${ }^{70}$ In the Yrusta case, this problem did not occur and was therefore not considered by the Committee.

The right to information can be limited when the following conditions are met. Deprivation of liberty is subject to judicial control. A person who is deprived of his or her liberty is protected by law. If the release of data indicated in Article 18 (1) would have an adverse effect on the security or privacy of the person deprived of liberty, or if it would impede the judiciary or otherwise be prejudicial within the meaning of national and international law, then the information may be restricted. A decision to restrict this information must have a legal basis in legislation and can only be taken in case of absolute necessity. The restriction of this information cannot result in any person's being secretly detained or subjected to enforced disappearance. ${ }^{71}$

The fulfilment of such conditions for restricting the right to information is not a simple matter, and does not often occur in practice, under democratic rule of law. The example of the Yrusta family trying to find basic information about the fate of their relative shows that is simpler for the public authorities to not provide any information or make it difficult for the relatives to obtain it by falsifying prisoner registers. Anticipation of such situations resulted in legitimate claimants being granted the right to an effective remedy, namely a means of obtaining the information sought without delay - a remedy which is separate from the question of the lawfulness of the deprivation of liberty. The law cannot be suspended or restricted regardless of the circumstances. ${ }^{72}$ Given the case file, it is evident that the right of Roberto Agustín Yrusta's relatives to an effective remedy was

69 Article $22 \mathrm{~A} / \mathrm{RES} / 61 / 177$. CED, Concluding observations on the report submitted by Burkina Faso under article 29, paragraph 1, of the International Convention for the Protection of all Persons from Enforced Disappearances, CED/C/BFA /CO/1, 24 May 2016, para. 34.

70 Article 19 A/RES/61/177.

71 Article 20 (1) A/RES/61/177.

72 CED, Concluding observations on the report submitted by Senegal under article 29, paragraph 1, of the International Convention for the Protection of all Persons from Enforced Disappearances, CED/C/SEN/CO/1, 18 April 2017, para. 34 (d). 
adversely affected by the refusal to allow them to participate in the investigation into his death, and by the protraction of their appeals in individual instances. Given that the authors of the communication were unable to enforce their right to information, the Committee ruled that this right had been violated with regard to the relatives of the disappeared and Mr. Yrusta himself. The literal wording of Article 18, however, suggests that the right established therein pertains not to persons deprived of liberty, but rather to those who seek information on them. Thus, for the Committee to express such an opinion about Mr. Yrusta's right, it could only have been on the assumption denying the right of Mr. Yrusta's relatives to information entailed that Mr. Yrusta received inadequate legal protection.

In the case in question there was found to have been a violation of the right to report the facts concerning enforced disappearance in the system of national law, as expressed in the first sentence of Article 12 (1) of the Convention. ${ }^{73}$ Since the State Party had accepted the provision, it should have created in its domestic law a means of reporting the alleged enforced disappearance of persons, a means for competent authorities to verify these reports, and a means for prosecuting and punishing the perpetrators. Anyone with real knowledge of enforced disappearance is authorized by the Convention to participate in the State's criminal procedure. Such a statement entails that the State has a corresponding obligation to take the reported information into account and treat it with seriousness, due to the gravity of the offense, which may lead to the investigation of a crime, as well as the obligation to provide appropriate support to those intending to present known facts to the investigator. The Committee did not interpret Article 12 (1) of the Convention as an independent editorial body, but by quoting the first sentence, in extenso, it made it the starting point for citing the first three paragraphs of Article 24, indicating their relationship and relevance to the Yrusta case. In this way, it became possible to demonstrate that the authors of the communication had the status of victim under the Convention ${ }^{74}$, that the family of the disappeared person had reason to report the disappearance of Mr. Yrusta ${ }^{75}$, that they were entitled to demand the truth about the circumstances of the enforced disappearance, about the progress and results of the investigation, and about his actual fate. ${ }^{76}$ The finding that the State had not taken measures to uphold those rights ${ }^{77}$ by refusing the status of parties to the prosecution, and delaying the proceedings that were to establish such status, subsequently led to the finding of the State Party to be in violation of Articles 12 (1) and 24 (1), (2) and (3) of the Convention.

73 In this regard, so far the Committee has not commented on the reports of the States.

74 Article 24 (1). CED, Concluding observations on the report submitted by France under article 29, paragraph 1, of the International Convention for the Protection of all Persons from Enforced Disappearances, CED/C/FRA /CO/1, 8 May 2013, para. 34.

75 Article 12 (1) A/RES/61/177.

76 Article 24 (2) A/RES/61/177.

77 Article 24 (2) and (3) A/RES/61/177. 
It is curious why - in the scope stated in the conclusions, somewhat in contrast to the main part - the Committee's views cover not only the family of the disappeared, but also Roberto Agustín Yrusta himself. This seems to be a misunderstanding, or it must be accepted that Article 12 (1) applies to the disappeared, which is possible, but not entirely correct. In contrast, the application of Article 24 (1), (2) and (3) to Mr. Yrusta for the same purposes as his family was not legitimate. The facts of the case indicated that he was undoubtedly a victim, as the Committee confirmed by statement that there was violation of Articles 1 and 2 with regard to Mr. Yrusta. The decision that there had been a violation of Article 24 (1) only reinforces this conclusion. The Committee could, however, have considered such a measure necessary to express its opinion on the violation of sections 2 and 3 of the same Article of the Convention. In this context, it should be noted that Mr. Yrusta's case file does not contain any mention of his disappearance. The deceased was not able to defend himself; especially considering his mistreatment after the disappearance seems to have intensified, and this discouraged efforts aimed at clarifying the situation. For obvious reasons, the prison authorities were not inclined to discover or rather reveal - the truth. As a result, the State failed to take measures to ascertain the circumstances of Mr. Yrusta's disappearance and to determine his whereabouts and $\mathrm{f}$ cilitate his release. In this respect, it was correct to decide that there had been a violation of Article 24 (2) and (3) of the Convention in relation to the disappeared.

In conclusion, it should be emphasized that the procedure for individual complaints specified in the Convention has begun to function in practice. A communication was filed, the case was recognized, and a decision was issued which stated that there had been numerous irregularities in the implementation of the ban on enforced disappearance by the Argentine authorities. It is of key importance that a problem was identified, and the Committee proposed the implementation of specific corrective measures. However, this positive side of the issue is diminished by the fact that in the proceedings before the Committee there has been almost no cooperation from the State Party, which ignored the views after it had been delivered. It is not possible to establish what has happened with the Yrusta case on the national level: whether the circumstances of Mr. Yrusta's disappearance were explained, and whether his family received adequate compensation. The failure of the Argentine Government to cooperate with the Committee to full extent, along with the advisory nature of the procedure and the non-binding character of the final decision may send a bad signal to other Parties to the Convention, perhaps making them liable to disregard its potential, both in substance and in the form of individual complaints. With regard to countries such as Argentina and the phenomenon of enforced disappearance, on which the international community has so far had little impact, this would be a great shame. 


\section{Bibliography}

American Convention on Human Rights adopted on November 22 1969, UNTS, vol. 1144, p. 123.

CED, Concluding observations on the report submitted by Serbia under article 29, paragraph 1, of the International Convention for the Protection of all Persons from Enforced Disappearances, CED/C/SRB/CO/1,16 March 2015.

CED, Concluding observations on the report submitted by Armenia under article 29, paragraph 1, of the International Convention for the Protection of all Persons from Enforced Disappearances, CED/C/ARM/CO/1,13 March 2015.

CED, Concluding observations the report submitted by Kazakhstan under article 29, paragraph 1, of the International Convention for the Protection of all Persons from Enforced Disappearances, CED/C/KAZ/CO/1,26 May 2016.

CED, Concluding observations on the report submitted by Argentina under article 29, paragraph 1, of the International Convention for the Protection of all Persons from Enforced Disappearances, CED/C/ARG/CO/1,12 December 2013.

CED, Concluding observations on the report submitted by Germany under article 29, paragraph 1, of the International Convention for the Protection of all Persons from Enforced Disappearances, CED/C/GER/CO/1,10 April 2014.

CED, Concluding observations on the report submitted by Netherlands under article 29, paragraph 1, of the International Convention for the Protection of all Persons from Enforced Disappearances, CED/C/NLD /CO/1,10 April 2014.

CED, Concluding observations on the report submitted by Iraq under article 29, paragraph 1, of the International Convention for the Protection of all Persons from Enforced Disappearances, CED/C/IRQ/CO/1,10 April 2014.

CED, Concluding observations on the report submitted by Iraq under article 29, paragraph 1, of the International Convention for the Protection of all Persons from Enforced Disappearances, CED/C/IRQ/CO/1,10 April 2014.

CED, Concluding observations on the report submitted by Burkina Faso under article 29, paragraph 1, of the International Convention for the Protection of all Persons from Enforced Disappearances, CED/C/BFA /CO/1, 24 May 2016.

CED, Concluding observations the report submitted by Kazakhstan under article 29, paragraph 1, of the International Convention for the Protection of all Persons from Enforced Disappearances, CED/C/KAZ/CO/1,26 May 2016.

CED, Concluding observations on the report submitted by Tunisia under article 29, paragraph 1, of the International Convention for the Protection of all Persons from Enforced Disappearances, CED/C/TUN/CO/1, 25 May 2016.

CED, Concluding observations on the report submitted by Montenegro under article 29, paragraph 1, of the International Convention for the Protection of all Persons from Enforced Disappearances, CED/C/MNE/CO/1,16 October 2015. 
CED, Concluding observations on the report submitted by Armenia under article 29, paragraph 1, of the International Convention for the Protection of all Persons from Enforced Disappearances, CED/C/ARM/CO/1, 13 March 2015.

CED, Concluding observations on the report submitted by Argentina under article 29, paragraph 1, of the International Convention for the Protection of all Persons from Enforced Disappearances, CED/C/ARG/CO/1, 12 December 2013.

CED, Concluding observations on the report submitted by Burkina Faso under article 29, paragraph 1, of the International Convention for the Protection of all Persons from Enforced Disappearances, CED/C/BFA /CO/1, 24 May 2016.

CED, Concluding observations on the report submitted by Senegal under article 29, paragraph 1, of the International Convention for the Protection of all Persons from Enforced Disappearances, CED/C/SEN/CO/1, 18 April 2017.

CED, Concluding observations on the report submitted by France under article 29, paragraph 1, of the International Convention for the Protection of all Persons from Enforced Disappearances, CED/C/FRA /CO/1, 8 May 2013.

Decision of 12 April 2016 of the CED no. 1/2013 in the case Yrusta v. Argentina, CED/ C/10/D/1/2013. General Assembly Resolution of 9 January 2003, UNTS, vol. 2375, p. $237, \mathrm{~A} / \mathrm{RES} / 57 / 199$.

Decision of 12 April 2016 of the CED no. 1/2013 in the case Yrusta v. Argentina, $\mathrm{CED} / \mathrm{C} / 10 / \mathrm{D} / 1 / 2013$.

General Assembly Resolution of 10 December 1984,UNTS, vol.1465, p. 85, A/RES39/46.

General comment of the Working Group on Enforced or Involuntary Disappearances on the definition of enforced disappearances, $\mathrm{A} / \mathrm{HRC} / 7 / 2$.

International Convention for the Protection of all Persons from Enforced Disappearance adopted by the General Assembly of the United Nations on 20 December 2006, UNTS, vol. 2716, A/RES/61/177.

Report of the CED, General Assembly Official Records, 72 Session, Supplement no. 56, A/72/76.

Report of the CED, General Assembly Official Records, 74 Session, Supplement no. 56, A/74/56, para. 59 .

<http://tbinternet.ohchr.org/_layouts/treatybodyexternal/SessionDetails1.aspx?Session $\mathrm{ID}=1102 \&$ Lang $=\mathrm{en} \geq$.

<http://www.ohchr.org/EN/NewsEvents/Pages/DisplayNews.aspx?NewsID=22090 \&LangID $=\mathrm{E}>$.

<http://tbinternet.ohchr.org/_layouts/TreatyBodyExternal/Treaty.aspx?CountryID=7 \&Lang=en $>$.

<http://www.cidh.oas.org/basicos/english/Basic4.Amer.Conv.Ratif.htm>. 
SUMMARY

\section{The Use of the "Dry Submarine" Technique and Other Allegations in Proceedings Before the United Nations Committee on Enforced Disappearances. Remarks on the Yrusta v. Argentina Case no. 1/2013}

The prohibition on enforced disappearances is one of the fundamental norms of contemporary international law which is intended to protect the individual from state repression. Under certain circumstances, a violation of the prohibition is recognized as a crime of international law. There are no exceptions to the implementation of the norm. Since the prohibition is a treaty, States must expressly agree to be bound by it. Not all States have done this, but some have, including Argentina. Despite this, Roberto Agustín Yrusta disappeared. His enforced disappearance was preceded by numerous and elaborate forms of evil, cruel and humiliating treatment. This paper seeks to answer the question of how international law can ensure effective enforcement of the prohibition on enforced disappearance.

Keywords: human rights law, United Nations Committee on Enforced Disappearances, Yrusta v. Argentina Case no. 1/2013.

Katarzyna Łasak, University of Gdańsk, Faculty of Law and Administration, Bażyńskiego 6, Gdańsk 80-309, Republic of Poland, e-mail: katarzyna.lasak@ug.edu.pl. 
